\title{
Two New Factors for the Evaluation of Scientific Performance: $U$ and $U^{\prime}$
}

\section{Bilimsel Performansın Değerlendirilmesi Için İki Yeni Faktör: $U$ ve $U^{\prime}$}

\author{
(D) Tayfun UZBAY* \\ Üsküdar University, Neuropsychopharmacology Application and Research Center, İstanbul, Turkey
}

\begin{abstract}
Scientific performance of researchers that translates into academic improvement, tenure position in universities and project grants are commonly evaluated by using some bibliometric indicators. These indicators can be calculated through total number of papers and citations, impact factors of publishing journals, impact of each paper or impact of total papers. In addition, scientific impact of individuals is also determined by some indexes such as Hirsch (h) index. All of these measures and indexes have several limitations. Scientific projects and publications are mostly collaborative and all collaborators do not contribute to these projects and publications equally. Thus, it is difficult to understand and analyze an individual's performance by the outputs coming from collaborative studies. Here, a new practice for evaluating individual scientific performance is proposed. $U$ and $U^{\prime}$ factors are able to detect a qualified article production capacity of the scientists producing from their research projects and studies objectively. Although these factors may not give an idea about their exact contributions and solutions on the specific scientific problems, $U$ factors will assist a more objective evaluation for individual scientific performance or productivity of the scientists than other tools such as $h$ factor and impact factor alone. Because $h$ factor excludes certain articles of researchers, in this paper, I propose to use $U$ factor instead of h for a more objective evaluation. Especially the $U^{\prime}$ factor may also be helpful for an objective selection in scientific awards, project grants and in appointing academical staff.
\end{abstract}

Key words: Bibliometric, grant, $\mathrm{h}$ index, impact factor, scientific performance, tenure

Öz

Araştırmacıların akademik gelişime dönüșen bilimsel performansı, üniversitelerde görev süreleri ve proje hibeleri, bazı bibliyometrik göstergeler kullanılarak değerlendirilmektedir. Bu göstergeler toplam makale sayısı ve atıflar, yayınlandıkları dergilerin etki faktörleri, her bir makalenin etkisi veya toplam makalelerin etkisi ile hesaplanabilir. Ayrıca bireylerin bilimsel etkileri de Hirsch (h) indeksi gibi bazı indeksler tarafından belirlenmektedir. Bu ölçümlerin ve indekslerin hepsinde çeşitli sınırlııklar vardır. Bilimsel projeler ve yayınlar çoğunlukla fazla sayıda kişi ile iş birliğini gerektirir ve tüm ortak çalışanlar bu projelere ve yayınlara eşit ölçüde katkıda bulunmaz. Dolayısıyla, bir bireyin performansını kolaboratif çalışmalardan gelen çıktılarla anlamak ve analiz etmek zordur. Bu makalede bireysel bilimsel performansı değerlendirmek için yeni bir uygulama önerilmiștir. $U$ ve U' faktörleri, bilimcilerin araștırma projelerinden ve çalışmalarından gelen çıktıların ürün niteliğini ve nitelikli üretim kapasitesini objektif olarak tespit edebilmektedir. Bu faktörler, belirli bilimsel problemler üzerindeki kesin katkılar ve çözümler hakkında bir fikir veremese de, $U$ faktörü, bilim insanlarının bireysel bilimsel performansı veya üretkenliği için, h faktörü ve etki faktörü gibi diğer araçlardan daha objektif bir değerlendirmeye yardımcı olacaktır. H faktörü, araştırmacıların bazı çalışmalarını göz ardı edebilmektedir ve bu makalede, daha objektif bir değerlendirme için $\mathrm{h}$ yerine $U$ faktörü kullanımı önerilmektedir. $U$ ' faktörü de özellikle bilimsel ödüllerde, proje hibelerinde ve akademik personelin atanmasında objektif bir seçim için yararlı olabilir.

Anahtar kelimeler: Bibliyometrik, hibe proje teşviki/burs, h indeksi, etki faktörü, bilimsel performans, sabit kadro hakkı

\section{INTRODUCTION}

Beginning the new century, bibliometric analyses have increasingly turned to arithmetical methods using the parameters such as the impact factor of the scientific journals in which those publications appear first or corresponding author publications, and calculation at some specific index values. In 2005, Jorge E. Hirsch who is an Argentine American physicist proposed h-index for detecting scientific output of a researcher.
The h-index is an indicator which measures both the apparent scientific impact and the scientific productivity of a researcher. The index is based on the set of the scientist's most cited reports and the number of times that they have been cited in other people's scientific reports. An individual has index $\mathrm{h}$ if $\mathrm{h}$ of (his/her) Np reports have at least $h$ citations each. Hirsch suggested that the h-index provides a better prediction for the future achievement than the other indicators such as number 
of papers, number of citations, and mean citations per paper.,2 Other suggested bibliometric methods that also provide more importance to very highly cited scientific reports, such as Jin et al.'s ${ }^{3} \mathrm{AR}$ index and Kosmulski's, ${ }^{4} \mathrm{H}^{2}$ index, probably suffer from the same weakness as total citation account does, because they will allocate the citations of highly cited reports equally to all co-authors without considering rank of names in the report. Egghe 5 also introduced g-index which isdefined as, "A researcher has index $g$, if $g$ is the highest number that his or her top g publications received (together) at least $\mathrm{g}^{2}$ citations.

These indexes are influenced by the citation database. Databases vary in respect to publication time span, subject, and variety of listed journals, may provide qualitatively and quantitatively different citation numbers for the similar articles. $^{6}$ For example, although Scopus is one of the largest citation database, it reflects only those scientific reports available after 1995. Thus, Thompson Reuters Web of Science, another popular database, may provide more precise evaluation of lifetime performance. Mazloumian ${ }^{7}$ evaluated citation info of almost 150.000 scientists from the Web of Science database and they suggested that the $h$ value is a well predictor for the future citations of both published and future papers. Many databases frequently express both of h-index and impact factor of individuals for general assessments.

Scientific projects and publications are mostly collaborative and all collaborators do not contribute to these projects and publications equally. However, scientific impact of individuals is determined by making metrics such as the total publications, citations and various remarks or indexes such as $h, A, C$ and $P$ indexes that are unidirectional and insufficient measurements. ${ }^{8}$ A collaboration effect on scientific output has been subjected to various studies. ${ }^{9-11}$ Total numbers of publications, citations or bibliometric techniques based on indexes such as h-index may not provide objective and relevant results every time, especially about evaluation of individual performance. Because h-index and some other similar indexes exclude a part of articles of the researchers, we can sometimes reach inflated or fractional results regarding individual performances.

In this study, it was aimed that h-index is improved through considering the impact factor of scientist which is a value obtained from dividing total citations to total publications. Thus, here, a new evaluation practice, $U$ and $U$ ' factors, is proposed for a more objective evaluation of scientist's individual productivity and performance.

\section{Method and Formulation}

What is $U$ factor?

$U$ factor is a value simply obtained from multiplication of the Hirsch index $(h)$ with the impact factor (if). Impact factor for an individual scientist is calculated by dividing total citations to total publications without taking into consideration the place of name in the article and impact of the published journal. For example, a scientist has 1000 citations for a total of 100 articles and his/her h-index is 20 . What is his/her factor?
$U=$ if $x h$

if $=\frac{1000}{100}=10$

$h=20$

$U=20 \times 10=200$

\section{What is $U$ factor?}

$U^{\prime}$ factor needs a more complex calculation and it gives us a very objective evaluation for individual productivity and performance of scientists, because it highlights specific own effort of the scientist within the total activity. For $U^{\prime}$ factor, firstly, general $U$ value of the scientist is calculated as described above. Then, $U_{s}$ value indicating the scientist's specific contribution by his/ her publications is calculated. For that purpose, the articles in which the scientist is the first name or is corresponding author are taken into consideration. Number of citations is counted exactly for these articles and the obtained value is divided into total number of articles in which the scientist's is the first name or is corresponding author for calculating if ${ }_{s}$ value. Then, the scientist's specific h-index including only the articles in which the author is the first name or is corresponding author, is calculated as $h_{s}$ Then, $U_{s}$ value is obtained by multiplying if with $h_{s}$. When we divided $U_{s}$ by $U_{;} U^{\prime}$ is obtained.

\section{A sample calculation for $U^{\prime}$}

There is a scientist who has a total of 100 articles and 1000 citations. He/she is the first author in 20 and corresponding author in 30 of total articles. Thus, he/she has 50 articles for $U^{\prime}$ calculation. In addition, the scientist has 500 citations obtained from these articles. Let's assume, his/her $h_{s}$ index is 12 according to these specific articles. What is the $U^{\prime}$ factor for this scientist?

First, we calculate general $U$ as mentioned above and $U$ is found as 200 .

$$
\begin{aligned}
& U=h \times \text { if }=20 \times 10=200 \\
& \text { if }=\frac{500}{50}=10 \\
& h_{S}=12 \\
& U_{S}=i f_{S} \times h_{S}=10 \times 12=120 \\
& U^{\prime}=U_{S}=\frac{120}{200}=0.6
\end{aligned}
$$

$U^{\prime}$ is an indicator of scientist's own contribution or significant contribution among his/him total publications. As the $U^{\prime}$ value grows and closes to 1 , it is understood that the scientist's own contribution in total publications is significant. As the $U^{\prime}$ value becomes smaller, it is understood that the scientist's own contribution in total publications is insignificant. In this example, because $U^{\prime}$ is found as 0.6 , the scientist's own contribution to the total articles can be accepted as qualified. Table 1 presents a proposed model for the level of the scientist's own or specific contribution according to $U$ and $U^{\prime}$. 
Table 1. Scientific performance levels according to and *

\begin{tabular}{lll}
$U$ & $U^{\prime}$ & Scientific level \\
\hline$\langle 100$ & $\langle 0.25$ & Low \\
\hline $100-200$ & $0.25-0.50$ & Moderate \\
\hline $201-400$ & $0.51-0.75$ & Qualified \\
\hline$>400$ & $>0.75$ & Outstanding \\
\hline
\end{tabular}

*In this table, and are independent from each other ( values do not reflect every time, vice versa). is a more available indicator of scientists' own contribution within their total activity. We can use as a more available indicator of researchers' general scientific effort.

\section{DISCUSSION AND CONCLUSION}

Academic researchers transfer their discoveries, new ideas and experimental observations to the scientific community by refereed printed papers in academic journals. Only biomedical sciences generate more than a million new scientific articles each year. These publications are the basic source for measuring the outputs of an individual scientist. The specific publications are also the expressions of intellectual discoveries expressed explicitly aiming to convey new ideas or information for further knowledge. Bibliometric indicators have been widely used to measure the performance of the scientific community in general and in particular, to assess the productivity of a scientist or an academic journal. ${ }^{12}$ While impact factor and annual total citation number are two of the most commonly used evaluative tools, they are also undoubtedly less sophisticated than other fieldnormalized approaches advanced by bibliometric applicators. ${ }^{13}$

Within all of the indices, Hirsch's h-index is undoubtedly the most known index. It has been used in most popular databases such as ISI Web of Science, Scopus and Google Scholar Academic. It is designed to develop on generally used metrics and it reflects the cumulative impact of an individual's effort. It is determined from the distribution of citations received by a researcher's publications. A researcher has Hirsch index $h$ if $h$ of his/her $N p$ publications have, at least, $h$ citations each. ${ }^{14}$ For example, a researcher who has an h-index of 10 must have published ten articles that each have at least ten citations. The h-index is becoming a reference instrument for career evaluation, and it has been considered by some institutions in allocation, promotion and funding choices. ${ }^{12,15}$

Because there are alterations in citation behavior in different subject areas, the impact factor alone should only be used to compare journals or scientists working on the similar subject. ${ }^{16}$ $\mathrm{H}$-index has also several limitations. This index is a promising general assessment of the quality of a young scientist's effort. ${ }^{17,18}$ Because the h-index cannot exceed the amount of underlying papers, we can even describe $h=0$ for fully inactive scientists. Sensitivity to performance changes of h-index is low. It can never decrease and is only weakly sensitive to the number of citations. This is the reason for the development of most of the other type of indices. Because h-index is size-dependent, the use of h-index as an only factor for the evaluation of the scientific occupation of a researcher is not adequate. ${ }^{19}$ In addition, in comparison with the cumulative number of citations, the h-index is not critically inflated by a small number of highly cited articles. Furthermore, the h-index considers scientific impact as well as productivity, and it is hardly influenced by self-citation. It could identify outstanding and successful scientists and could facilitate academic improvement in divisions, universities, and other academic frames. ${ }^{14}$ Similar to mean citations per publication, the h-index shows a positive correlation with time. Furthermore, like other indexes, the h-index does not consider the background of citations, for example, those citations with a negative background that show inadequate or limited published article will have the effect of increasing the ranking of scientists when citation indices are used. ${ }^{20}$ Thus, $U$ factor presenting in our study may enable more objective and effective evaluation for individual scientific performance as compared to individual impact and $h$ factors since it combines both impact and $h$. Indeed, $U$ factor obtained by multiplying $h$ value and impact may be a new and useful metric in the scientometrics and seems to eliminate some limitations generating from impact factor and $\mathrm{h}$-index alone. Multiplying of $\mathrm{h}$-index with the impact factor of individual provides a correction in h-index and allows a more objective evaluation of scientists' performance.

One of the most important problems in evaluation of individual scientific performance is the papers with multiple names. This kind of studies are generally multidisciplinary. However, we can also see many articles with numerous names in a sole scientific area especially in life sciences and medicine. Some of them is also a gift authorship which is defined as lack of significant contribution of the author to the manuscript or study. They are best opportunistic and worse scientific misconducts. $^{21-23}$ An important question is that how we can detect a significant individual scientific performance and his/ her specific contribution to any scientist who has highly cited articles with multiple names?

Any scientist could have too many articles and could have a very high citation number too. Therefore, he/she could also have very high impact factor and high degree in h-index. However, this high impact value and high h-index do not show that this scientist is always qualified or a senior scientist. Thus, rank of the name in the article becomes an important determinant. Being first name or a corresponding author in the article indicates a significant contribution to the study. Thus, the number of the articles of a scientist in which his/her name appears as first name or corresponding author within the total articles and citations for these articles within the total citations are noteworthy indicators for the individual's own specific effort in the total articles and citations. $U$ ' directly gives us an objective opinion about the scientist's own specific effort in the related scientific zone. The most important benefit of $U^{\prime}$ in evaluation of individual scientific performance is sorting out of the publications regarding gift, honorary or guest authorship. If the scientist's $U^{\prime}$ is much smaller than 1 , he/she will have so much gift or guest authorship in his/her articles.

While $U$ can be used as an individual indicator like $h$ or the similar factors, $U^{\prime}$ can mainly be used for detecting the scientists' outstanding scientific activity within the total and 
together with $U$, for instance, it may be useful for an objective evaluation in competitive statements such as award, grant and tenure position in universities. If a scientist has $U^{\prime}$ that is closer to 1 or more than 1, that means he/she has a significant direct contribution to the studies turning into publication in the same extent. A $U^{\prime}$ value too much lower than 1 indicates that the scientist has not a direct relation or contribution to the studies that result in publication. This statement could also imply too much gift, honorary or guest authorship. A scientist who has a very low $U^{\prime}$ value, even if he/she has a high citation count and a high $\mathrm{h}$ index, cannot be accepted as outstanding or senior researcher in the scientific community.

Evaluation of $U^{\prime}$ will help a more equal selection in the competitive statements of the science i.e. award, grant allocation or tenure positions. However, the main problem for $U^{\prime}$ evaluation is that there is a possibility for detecting a high $U^{\prime}$ value in the individuals who have low publication and citation counts. This problem can be overcome by making comparison of the individuals who have an acceptable threshold value. The threshold value can be detected according to an acceptable $U$ value obtained from a suitable $\mathrm{h}$ index and impact factor. For example, according to property of competition, a borderline value can be defined and the individuals who have a lower borderline value are not included in the evaluation.

Currently, an apparent problem is that there is not a software regarding practical calculation of these values provided by any database. Thus, calculation seems to be a bit difficult and time-consuming. However, a freely available software simply presents a solution for this problem and will make the calculation easier.

In conclusion, here, new practical indexes for assessment of individual scientific performance have been presented. These indexes may be useful for selection in competitive scientific statements and they seem to be more effective than h-index or impact alone. Thus, we have used successfully this method for evaluating the performance of the scientists from pharmaceutical sciences during detection of science awards and grants of Turkish Pharmacists' Association, Pharmacy Academy since 2007. We observed that $U$ and $U^{\prime}$ factors are practical, equitable and more effective than $\mathrm{h}$ for individual evaluation of scientific performance.

\section{ACKNOWLEDGEMENTS}

Author would like to thank to Dr. Serhat Özekes and Dr. Ahmet Can Timuçin for their valuable comments for the manuscript. Turn-it-in program was used for checking plagiarism (9\%) in this manuscript.

Conflict of Interest: No conflict of interest was declared by the authors.

\section{REFERENCES}

1. Hirsch JE. An index to quantify an individual's scientific research output. Proc Natl Acad Sci USA. 2005;102:16569-16572.
2. Hirsch JE. Does the $\mathrm{H}$ index have predictive power? Proc Natl Acad Sci USA. 2007;104:19193-19198.

3. Jin B, Liang L, Rousseau R, Egghe L. The R- and AR- indices: Complementing the h-index. Chin Sci Bull. 2007;52:855-863.

4. Kosmulski M. A new Hirsch-type index saves time and works equally well as the original h-index. ISSI Newsletter. 2006;2:4-6.

5. Egghe L. Theory and practice of the g-index. Scientiometrics. 2006;69:131-152.

6. Kulkarni AV, Aziz B, Shams I, Busse JW. Comparisons of citations in Web of Science, Scopus, and Google Scholar for articles published in general medical journals. JAMA. 2009;302:1092-1096.

7. Mazloumian A. Predicting scholars' scientific impact. PLoS One. 2012;7:e49246.

8. Stallings J, Vance E, Yang J, Vannier MW, Liang J, Pang L, Dai L, Ye I, Wang G. Determining scientific impact using a collaboration index. Proc Natl Acad Sci USA. 2013;110:9680-9685.

9. Foulkes W, Neylon N. Redefining authorship. Relative contribution should be given after each author's name. BMJ. 1996;312:1423.

10. Campbell P. Policy on papers' contributors. Nature. 1999;399:393.

11. Ball P. A longer paper gathers more citations. Nature. 2008;455:274275.

12. Hadagali GS, Kumbar BD, Gourikeremath GN, Hiremath R. g-index as an improvement of the h-index: A comparative study of prominent Indian scientists. Int J Inf Dissem Tec. 2016;(Suppl 1):42-48.

13. Hutchins BI, Yuan X, Anderson JM, Santangelo GM. Relative citation ratio (RCR): A new metric that uses citation rates to measure influence at the article level. PLOS Biol. 2016;14:e1002541.

14. Ball P. Achievement index climbs the ranks. Nature. 2007;448:737.

15. Garcia-Perez MA. A multidimensional extension to Hirsch's h-index. Scientiometrics. 2009;81:779-785.

16. Jones T, Huggett $S$, Kamalski J. Finding a way through the scientific literature: Indexes and measures. World Neurosurg. 2011;76:36-38.

17. Bornmann L, Daniel HD. Does the h-index for ranking of scientists really work? Scientiometrics. 2005;65:391-392.

18. Bornmann L, Daniel HD. What do we know about the h-index? J Am Soc Inf Sci Tec. 2007;58:1381-1385.

19. Costas R, Bordons M. The h-index: Advantages, limitations and its relation with other bibliometric indicators at the micro level. $J$ Informetr. 2007;1:193-203.

20. O'Leary JD, Crawford MW. Bibliographic characteristics of the research output of pediatric anesthesiologists in Canada. Can J Anaesth. 2010;57:573-577.

21. Gasparyan AY, Ayvazyan L, Kitas GD. Authorship problems in scholarly journals: Considerations for authors, peer reviewers and editors. Rheumatol Int. 2013;33:277-284.

22. Rajasekaran S, Shan RL, Finnoff JT. Honorary authorship: frequency and associated factors in physical medicine and rehabilitation research articles. Arch Phys Med Rehabil 2014;95:418-428.

23. Harvey LA. Gift, honorary or guest authorship. Spinal Cord. 2018;56:91. 